\title{
Jurist-Diction
}

Volume 3 No. 6, November 2020

\section{Penyiaran Program Siaran "86" di Media Televisi Perspektif Hukum Pidana}

Putri Riska Answendy

putri.riska.answendy-2016@fh.unair.ac.id

Universitas Airlangga

How to cite:

Putri Riska Answendy,

'Penyiaran Program Siaran

"86" di Media Televisi

Perspektif Hukum Pidana' (2020) Vol. 3 No. 6 November Jurist-Diction

Histori artikel:

Submit 18 Agustus 2020;

Diterima 11 September 2020;

Diterbitkan 1 November 2020.

DOI:

10.20473/jd.v3i6.22974

\begin{abstract}
Abstrak
Program Siaran "86" merupakan salah satu produk pers yang disirkan melalui media televisi. Komisi Penyiaran Indonesia (KPI) mengolongkan program ini dalam program siaran jurnalistik. Materi isi siaran program ini adalah penayangan proses sebelum adanya putusan dari pengadilan yang dilakukan oleh kepolisian. Dalam penanyangannya seringkali melibatkan adanya kekerasan dan tidak mengindahkan hak anak. Hal ini membuka peluang adanya pelangaran terhadap asas praduga tak bersalah karena isi dari siaran ini adalah proses sebelum adanya putusan dari pengadilan, sehingga pihak yang terlibat dapat dinilai bersalah oleh masyarakat karena penayangan program acara ini. Berdasarkan latar belakang tersebut akan dibahas permasalahan terkait apakah penayangan Program Siaran "86" merupakan perbuatan yang melanggar peraturan perundang-undangan dan kode etik serta apakah bentuk tanggung jawab media televisi yang menyiarkan Program Siaran "86" tersebut. Untuk mendapatkan jawaban atas pertanyaan tersebut digunakan pendekatan perundangundangan dan pendekatan konseptual. Dari pendekatan tersebut didapatkan kesimpulan bahwa penayanagan Program Siaran "86" dimedia televisi diperbolehkan oleh peraturan perundang-undangan dan kode etik namun, isi materi siaran dalam program tersebut masih menyalahi peraturan yang ada sehingga patut untuk dimintai pertanggungjawaban.

Kata Kunci: Program Siaran "86"; Program Siaran Jurnalistik; Asas Praduga Tak Bersalah.
\end{abstract}

\section{Pendahuluan}

Dalam era globalisasi peran dan posisi informasi dalam masyarakat menjadi hal yang sangat penting. Sumber informasi yang hingga saat ini masih di percaya oleh masyarakat luas adalah pemberitaan yang diberikan oleh pers. Kepercayaan tersebut menuntut pers untuk memberikan informasi terkini. Kondisi ini membuat kebebasan dalam menyampaikan dan mendapatkan informasi menjadi tidak terbatas. Kebebasan pers dijamin dalamketentuan Pasal 28 F UUD 1945, yang menyatakan setiap orang berhak untuk berkomunikasi dan memperoleh informasi 
untuk mengembangkan pribadi dan lingkungan sosialnya, serta berhak untuk mencari, memperoleh, memiliki, menyimpan, mengolah, dan menyampaikan informasi dengan menggunakan segala jenis saluran yang tersedia.

Secara etimologis istilah Pers (Belanda), Press (Inggris), Presse (Prancis) berarti tekan atau cetak. Kata ini berasal dari bahasa Latin, Pressae dari kata Premere sehingga definisi terminologinya adalah media massa cetak. Secara harfiah pers berarti cetak sehingga dapat dimaknai sebagai publikasi dalam bentuk yang tercetak. ${ }^{1}$ Undang-undang Nomor 40 Tahun 1999 tentang Pers (UU Pers)mengartikan pers sebagai lembaga sosial dan wahana komunikasi massa yang melaksanakan kegiatan jurnalistik meliputi mencari, memperoleh, memiliki, menyimpan, mengolah, dan menyampaikan informasi baik dalam bentuk tulisan, suara, gambar, suara dan gambar, serta data dan grafik, maupun dalam bentuk lainnya dengan menggunakan media cetak, media elektronik, dan segala jenis saluran yang tersedia. Berangkat dari pengertian tersebut maka produk dari pers tidak hanya terbatas pada media cetak saja namun juga media elektronik yang salah satunya adalah media televisi.

Media Televisi merupakan salah satu alat yang digunakan oleh pers untuk menyampaikan informasi dalam bentuk suara dan gambar. Dalam menyampaikan informasi pada media televisi terdapat proses menyiarkan yang dalam UndangUndang Nomor 32 Tahun 2002 tentang Penyiaran (UU Penyiaran)berarti pesan atau rangkaian pesan dalam bentuk suara, gambar, atau suara dan gambar atau yang berbentuk grafis, karakter, baik yang bersifat interaktif maupun tidak, yang dapat diterima melalui perangkat penerima siaran. Penyiaran televisi harus memenuhi fungsi dan kewajibannya sesuai Pasal 3 dan Pasal 5 ayat (1) UU Pers, salah satu kewajiban pers adalah terkait asas praduga tak bersalah.Asas praduga tak bersalah adalah asas yang secara implisit terkandung dalamPasal 66 Undang-undang Nomor 8 Tahun 1981 tentang Kitab Undang-undang Hukum Acara Pidana (KUHAP) yang menegaskan tersangka atau terdakwa tidak dibebani kewajiban pembuktian. Dalampenjelasan pasal tersebut juga dirumuskan bahwa ketentuan dalam Pasal 66 [145].

${ }^{1}$ Onong Uchyana Effendi, Ilmu Komunikasi (Teori dan Praktek) (Remaja Rasdakarya 2002). 
KUHAP tersebut merupakan penjelmaan dari asas praduga tak bersalah. ${ }^{2}$

Penyiraan televisi dalam membuat program acara memperhatikan fungsi maupun kewajiban dari pers, termasuk menghormati asas praduga tak bersalah. Tanpa disadari atau tidak penyiaran televisi kerap kalimemberikan informasi yang disertai dengan sebuah opini atau pendapat terkait dengan informasi yang diberikan, sehingga berujung pada penghakiman terhadap informasi yang diberikan. Pemberitaan seperti itu dapat memengaruhi pola pikir dan pandangan seseorang terkait kasus dan setiap pihak yang terlibat. ${ }^{3}$ Trial by press atau trial by media terjadi ketika media massa memuat suatu kasus yang berisi tuduhan serta penghakiman terhadap tersangka bahkan sebelum pengadilan mengeluarkan putusan terhadap kasus tersebut, sehingga merupakan bentuk interferensi pada proses pengadilan.

Komisi Penyiaran Indonesia (KPI) merupakan lembaga negara independen. KPI mengeluarkan sebuah aturan yaitu Peraturan Komisi Penyiaran Indonesia Nomor 02/P/KPI/03/2012 tentang Standar Program Siaran. Dalam pasal 1 ayat 1 Standart Program Siaran telah diterangkan secara jelas Standar program siaran adalah standar isi siaran yang berisi tentang batasan-batasan, pelarangan, kewajiban, dan pengaturan penyiaran, serta saksi berdasarkan Pedoman Perilaku yang ditetapkan oleh KPI. Media televisi dalam meyiarkan program acara nya harus memastikan bahwa program acara tersebut memenuhi standar yang dikeluarkan oleh KPI. Salah satu program acara televisi yang perlu di tindak lanjuti adalah program siaran jurnalistik yang berisi penayangan proses sebelum adanya putusan dari pengadilan. Salah satu program acara yang dimaksud berjudul "86" (selanjutnya disebut Program Siaran“86") yang ditayangkan pada salah satu stasiun televisi swasta yaitu NET TV, produksi program ini merupakan hasil kerjasama NET TV dengan Kepolisian Negara Republik Indonesia yang bertujuan untuk menujukan bagaimana keseharian dari anggota kepolisian. Program tersebut memperlihatkan anggota kepolisian yang

${ }^{2}$ Loebby Loqman, 'Asas Praduga Tak Bersalah di dalam Pemberitaan oleh Media Massa' (2010) 2 Jurnal Dewan Pers.[2].

${ }^{3}$ Hanugrah Titi Habsari, 'Implikasi Hukum Asas Praduga Bersalah yang Digunakan Wartawan dalam Pemberitaan Perkara Pidana’ (2017) 2 Arena Hukum.[290]. 
melayani negara, dari mulai menertibkan pelanggar lalu lintas, penggerebekan (seperti penipuan, perampokan, pembunuhan,dan lain-lain), hingga pengungkapan sindikat narkoba dan miras disertai penceritaan ulang dari anggota kepolisian yang terlibat sehingga seringkali menciptakan keadaan yang memperburuk objek yang disiarkan karena adanya opini dan pendapat dari anggota kepolisian yang terlibat. Penyiaran program acara tersebut menciptakan adanya perbuatan menghakimi yang berujung pada pengabaian asas praduga tak bersalah. Keberadaan program ini pada media telivisi secara langsung dan tidak langsung merugikan bagi pihak yang terlibat dan belum sepenuhnya terbukti bersalah.

\section{Penayangan Program Siaran "86"}

Tayangan berjudul Program Siaran " 86 " adalah sebuah program siaran yang disajikan oleh salah satu stasiun televisi swasta di Indonesia. Program ini tayang perdana pada 2 Agustus 2014, hal ini menunjukan bahwa hampir 6 tahun lamanya program ini dipercaya oleh masyarakat Indonesia. Program ini juga merupakan program unggulan dari $N E T T V$. Hal yang patut menjadi pehatian lain adalah Program Siaran " 86 "merupakan pelopor dari tayangan dengan subjek polisi yang kini mulai menjamur di dunia pertelevisian,

Isi siaran Program Siaran " 86 " adalah anggota kepolisian yang sedang bertugas mulai menertibkan pelanggarlalu lintas,penggerebekan (seperti penipuan, perampokan, pembunuhan,danlain-lain), hingga pengungkapan sindikat narkoba dan miras dengan disertai narasi dari anggota kepolisan yang bersangkutan. Format acara yang demikian ini disebut degan Cinéma vérité yang merupakan salah satu gaya penyutradaraan film dokumenter, berisi adegan kejadian, pengutaraan emosi dari subjek dan penggalan narasi untuk memperjelas kejadian. ${ }^{4}$ Hal ini juga ditemukan pada program acara “Cops” yang ditayangkan Paramount Network saluran televisi berbayar di Amerika Serikat, program ini telah berjalan

\footnotetext{
${ }^{4}$ Amanda Paramitha, 'Karya Film Dokumenter mengenai Kehidupan Seorang Anak Perantau dari Kabupaten Alor, Nusa Tenggara Timur di Pesantren At-Tamim Kabupaten Bandung’ (2017) Program Sarjana Universitas Pasudan.[12].
} 
sejak tahun 1989 hingga saat ini. Selain memiliki format gaya penyutadaraan yang sama kedua program ini juga memiliki kesamaan subjek yaitu pihak Anggota Kepolisian.

Pada bagian pembuka program Cops memberi peringatan kepada penonton "Cops is filmed on location with the men and women of law enforcement all suspects are innocent until proven guilty in a court of law" (Cops difilmkan di lokasi dengan para penegak hukum, semua tersangka tidak bersalah sampai dibuktikan bersalah di depan pengadilan). Pernyataan tersebut menunjukan bahwa acara ini menghormati keberadaan asas presumption of innocence. Asumsi yang timbul pada penonton menjadi hal yang penting di AS karena sistem hukum yang berlaku adalah Common Law yang mana dapat ditemukan keberadaan penegak hukum yang disebut dengan Juri. ${ }^{5}$ Posisi juri bisa di diisi oleh siapapun maka dari itu presumption of innocence yang di tegaskan pada bagian pembuka memiliki arti penting karena semua penonton dari program acara tersebut memiliki kemungkinan untuk menjadi juri dari kasus yang disiarkan. Nantinya juri diharuskan untuk mempertimbangkan bukti dan kesaksian dalam menentukan pertanyaan-pertanyaan tentang fakta. ${ }^{6}$

Komisi Penyiaran Indonesia (Selanjutnya disebut KPI) sebagai lembaga yang dipercaya oleh Pemerintah memberi label program acara dengan format yang sama yaitu Program Siaran "86” kedalam kategori Program siaran jurnalistik.Roan Y. Anpira selaku Kepala Divisi Programming dan Produksi NET TV menyatakan bahwa "Melalui program 'Program Siaran "86", kami berharap masyarakat Indonesia dapat menyadari pentingnya mematuhi aturan-aturan yang berlaku, menghargai dan membantu pihak kepolisian. Caranya bisa dimulai dari mendisiplinkan diri kita sendiri terlebih dulu. Harapan kami dengan menayangkan 'Program Siaran "86", masyarakat dapat lebih bijak dalam menentukan sikap terhadap peraturan-peraturan

${ }^{5}$ Soediro, 'Perbandingan Sistem Peradilan Pidana Amerika Serikat dengan Peradilan Pidana di Indonesia' (2019) Kosmik Hukum.[54].

${ }^{6}$ Nevrina Hastuti, "Eksistensi Sistem Juri dalam Sistem Peradilan Pidana Amerika Serikat", <https://jabar.kemenkumham.go.id/berita-kanwil/berita-utama/eksistensi-sistem-juri-dalam-sistem-peradilan-pidana-amerika-serikat>, accessed on 10 May 2020. 
negara" dari peryataan tersebut dapat dilihat tujuan awal dari pembuatan acara ini adalah:

1. Kesadaran masyarakat terkait pentingnya mematuhi aturan-aturan yang berlaku;

2. Kesadaran masyarakat dalam menghargai dan membantu pihak kepolisian.

Berbeda dengan Cops yang memberikan peringatan pada bagian pembukaprogram acaranya, Program Siaran " 86 " ditemukan tidak memberikan peringatan yang sama. Indonesia sendiri telah meratifikasi konvenan Internasional tentang Hak Sipil dan Politik pada 28 Oktober 2005 melalui Undang-Undang Nomor 12 Tahun 2005 tentang Pengesahan International Covenant On Civil And Political Rights8yang berarti Indonesia juga mengakui keberadaan Pasal 14 paragraf 2 tersebut. Indonesia telah mengenal asas ini dengan nama asas praduga tidak bersalah. Landasan hukum atas asas praduga tidak bersalah juga ditemukan secara khusus dalam hukum pers, pengaturan asas hukum asas praduga tidak bersalah secara umum juga mendasari hukum acara dan penegakan hukum (law enforcement).Ini menujukan bahwa asas ini sama pentingnya pada sistem hukum Civil Law yang dianut di Indonesia meskipun tidak ditemukan adanya keberadaan Juri.

\section{Pengaturan dalam Undang-Undang Pers}

UU Pers dibuat untuk melindungi hak dan kinerja secara khusus bagi wartawan dalam melaksanakan tugas dan fungsinya9maka dari itu hanya ada tiga ayat berkaitan dengan pemidanaan yang dapat digunakan untuk menjerat Lembaga Pers. Dalam Pasal 5 ayat (1) dijelaskan bahwa Perusahaan Pers Nasional berkewajiban memberitakan peristiwa dan opini dengan menghormati norma-norma agama dan rasa kesusilaan masyarakat serta asas praduga tak bersalah apabila dilanggar dalam

7 Adv, "86 Program TV Baru yang Mengungkap Realita Kehidupan Polisi". <https://hot. detik.com/advertorial-news-block/d-2655975/`86'-program-tv-baru-yang-mengungkap-realita-kehidupan-polisi>, accessed on 15 May 2020.

8 "Mengenal Konvenan Internasional Hak Sipil dan Politik", <https://icjr.or.id/mengenal-kovenan-internasional-hak-sipil-dan-politik/>, accessed on 28 May 2020

${ }^{9}$ Pretty BellaWajong, 'Perlindungan Hukum bagi Wartawan dalam Melaksankan Tugas dan Fungsi Terkait dengan Kebebasan Pers menurut Undang-Undang Nomor 40 Tahun 1999' (2018) 2 Lex Et Societatis.[55]. 
Pasal 18 ayat (2) dijelaskan adanya keberadaan pemidanaan dengan pidana denda paling banyak Rp. 500.000.000,00(Lima ratus juta rupiah). Makna dari asas praduga tak bersalah disini adalah pers dalam pemberitaannnya tidak boleh menghakimi ${ }^{10}$ Tujuannya adalah agar tidak timbul tindakan trial by the press yang ditakutkan akan mempengaruhi jalannya proses penegakan hukum. ${ }^{11}$

\section{Pengaturan dalam Undang-Undang Penyiaran}

Undang-Undang Nomor 32 Tahun 2002 tentang Penyiaranbanyak mengatur terkait lembaga penyiaran. ${ }^{12}$ Undang-undang ini merupakan lex speciali bagi UU Pers karena fokusnya akan lembaga penyiaran yang merupkan bagian dari media elektronik. Lembaga penyiaran adalah penyelenggara penyiaran, baik lembaga penyiaran publik, lembaga penyiaran swasta, lembaga penyiaran komunitas maupun lembaga penyiaran berlangganan yang dalam melaksanakan tugas, fungsi, dan tanggung jawabnya berpedoman pada peraturan perundang-undangan yang berlaku. Penyiaran televisi merupakan bagian dari penyelengaraan penyiaraan yang diatur dalam UU ini.

Agar kebebasan ini tidak digunakan secara sembarangan dalam Pasal 5 huruf I Penyiaran diarahkan untuk memberikan informasi yang benar, seimbang, dan bertanggung jawab. Sehingga materi siaran Program Siaran " 86 " yang merupakan pemberitaan sebelum putusan pengadilan harus berisikan informasi yang benar seimbang dan bertanggung jawab agar asas praduga tak bersalah dapat dilindungi sesuai dengan Pasal 18 ayat (2) UU Pers.

Pasal 36 ayat (5) dijelaskan mengenai larangan isi siaran yaitu:

a. Bersifat bersifat fitnah, menghasut, menyesatkan dan/atau bohong;

b. menonjolkan unsur kekerasan, cabul, perjudian, penyalah-gunaan narkotika dan obat terlarang; atau

\footnotetext{
${ }^{10}$ Sukardi, W. A., 'Menghindari Tuduhan Pelanggaran Asas Praduga Tidak Bersalah' (2010) 2 Jurnal Dewan Pers.[20].

${ }^{11}$ Loebby Loqman, Op.Cit.[10].

${ }^{12}$ Hermin Indah Wahyuni, Kebijakan Media Baru Di Indonesia (Harapan Dinamika dan Capaian Kebijakan Media Baru Di Indonesia) (Ugm Press 2018).[52].
} 
c. mempertentangkan suku, agama, ras, dan antargolongan.

Poin b pada larangan ini jelas muncul dalam Program Siaran "86" karena seperti yang di jelaskan sebelumnya pengungkapan sindikat narkoba dan miras juga merupakan isi dari program ini. Selain itu pada proses pengerebekan juga mempertunjukan unsur kekerasan. Pasal 36 ayat (3) dijelaskan bahwa isi siaran wajib memberikan perlindungan dan pemberdayaan kepada khalayak khusus, yaitu anak-anak dan remaja, dengan menyiarkan mata acara pada waktu yang tepat, dan lembaga penyiaran wajib mencantumkan dan/atau menyebutkan klasifikasi khalayak sesuai dengan isi siaran juga patut menjadi perhatian karena sering kali pengerebekan dilakukan kepada anak-anak dan remaja yang melakukan kesalahan di jalanan.

Pasal 8 ayat (2) huruf d dijelaskan bahwa KPI mendapatkan wewenang untuk memberikan sanksi terhadap pelanggaran peraturan dan pedoman perilaku penyiaran serta standar program siaran. Keduanya ditetapkan oleh KPI pada tahun 2012. Didalam peraturan ditemukan pengkategorian secara khusus bagi program siaran dengan label Program Siaran Jurnalistik.

1. Pedoman Prilaku Penyiaran merupakan aturan yang dikeluarkan oleh KPI berdasarkan pada Peraturan Komisi Penyiaran Indonesia Nomor 01/P/ KPI/03/2012 tentang Pedoman Perilaku Penyiaran.Berdasarkan pasal 22 ayat (4) Lembaga penyiaran wajib menerapkan prinsip praduga tak bersalah dalam peliputan dan/atau menyiarkan program siaran jurnalistik. Inilah benang merah penegakan asas praduga tak bersalah pada lex speciali. Pelanggaran yang dilakukan oleh program siaran jurnalistik berdasarkan data yang dimuat pada website KPI berkaitan dengan Pasal 14 mengenai perlindungan kepada anak, Pasal 17 mengenai pembatasan program siaran bermuatan kekerasan, dan Pasal 22 ayat (1), (2), dan (3) mengenai prinsip-prinsip jurnalisik. ${ }^{13}$

\footnotetext{
${ }^{13}$ Risa Badril Moenir, 'Kecenderungan Pelanggaran Pedoman Perilaku Penyiaran dan Standar Program Siaran (Studi Analisis Pada Kasus Pelanggaran Pedoman Perilaku Penyiaran dan Standar Program Siaran Media Televisi yang Dimuat di Website kpi.go.id)', 1 Jurnal Ilmu Komunikasi Flow.[8].
} 
2. Standar Siaran Jurnalistik berdasarkan pada Peraturan Komisi Penyiaran Indonesia Nomor 02/P/KPI.03/2012 tentang Standar Program Siaran.Dalam pasal 1 angka ayat (1) telah dijelaskan bahwa Standar Program Siaran adalah standar isi siaran yang berisi tentang batasan-batasan, pelarangan, kewajiban, dan pengaturan penyiaran, serta sanksi berdasarkan Pedoman Perilaku Penyiaran yang ditetapkan oleh KPI. Pasal 10 telah diterapkan dengan sangat baik oleh Program Siaran "86" karena tim produksi Program Siaran "86" mengakui adanya pembentukan realitas untuk menampilkan polisi dalam citra posotif ketimbang negatif. ${ }^{14}$ Ini sesuai dengan isi Pasal 10 yaitu Program siaran wajib menghormati etika profesi yang dimiliki oleh profesi tertentu yang ditampilkan dalam isi siaran agar tidak merugikan dan menimbulkan dampak negatif di masyarakat.Pengakuan tim produksi Program Siaran "86" menimbulkan pertanyaan karena pada pasal 11 yang menyatakan program siaran dimanfaatkan untuk kepentingan publik dan tidak untuk kepentingan kelompok tertentu, apabila program ini menampilkan citra positif polisi maka manfaat utama diperoleh oleh kelompok tertentu yaitu Lembaga Kepolisian karena proogram ini membuat masyarakat berasumsi bahwa semua polisi memiliki karakter yang sama dengan apa yang di siarkan oleh Program Siaran " 86 ” padahal tidak dapat pungkiri kenyataannya masih dapat ditemukan polisi yang berkarakter negatif .

Sebelumnya telah dijelaskan bahwa Program Siaran " 86 " pernah memperoleh teguran tertulis akibat menayangkan anak-anak dan remaja, pada pasal 15 ayat 3 dijelaskan bahwa Program Siaran yang menampilkan anak-anak dan/atau remaja dalam peristiwa/penegakan hukum wajib disamarkan wajah dan identitasnya. Program Siaran " 86 ” juga sering kali menayangkan pengerebakan yang rawan akan adegan kekerasan sebagai contoh perlakuan Tim Tiger Polres Metro Jakarta Utara yang ditayangkan pada bulan April 2020 pada pelaku tawuran, tim produksi Program Siaran "86” terlihat menyamarkan pelaku namun di satu

${ }^{14}$ Muhammad Imam Baihaqi, Konstruksi Realitas Sosial Citra Polisi Pada Reality Show Net Program Siaran "86” Di Net. TV (2016) Program Master UIN Syarif Hidayatulah Jakarta.[50]. 
titik dapat ditemukan bentuk kekerasan yang lepas dari sensor tim produksi, ${ }^{15}$ adegan kekerasan yang ditampilkan harusnya mengikuti standar pada pasal 23.

\section{Penayangan Program Siaran "86" berdasarkan Kode Etik Jurnalistik}

Kode etik adalah norma dan asas yang diterima oleh suatu kelompok tertentu sebagai landasan tingkah laku. ${ }^{16}$ Kode Etik Jurnalistik adalah standar nilai yang harus dijadikan acuan bagi wartawan dalam menjalankan profesi kewartawanan. ${ }^{17}$ Etika jurnalistik ini tidak hanya untuk memelihara dan menjaga standar kualitas pekerjaan si jurnalis bersangkutan, tetapi juga untuk melindungi atau menghindarkan khalayak masyarakat dari kemungkinan dampak yang merugikan dari tindakan atau perilaku keliru dari si jurnalis bersangkutan. ${ }^{18}$ Program Siaran "86" yang merupakan produk Jurnalistik mengikuti Kode Etik Jurnalistik sebagai acuan moral dalam pembuatan isi siarannya.

Kode etik yang digunakan adalah Kode Etik Jurnalistik ditetapkan Dewan Pers melalui Peraturan Dewan Pers Nomor: 6/Peraturan-DP/V/2008 Tentang Pengesahan Surat Keputusan Dewan Pers Nomor 03/SK-DP/III/2006 tentang Kode Etik Jurnalistik Sebagai Peraturan Dewan Pers di Jakarta pada tanggal 14 Maret 2006. Pasal 4 yang menyatakan Wartawan Indonesia tidak membuat berita bohong, fitnah, sadis, dan cabul patut menjadi perhatian. Apabila melihat format isi Program Siaran "86" maka dapat diketahui bahwa isi program ini berisi fakta terkait pekerjaan dari anggota kepolisian, yang ditakutkan adalah akan timbulnya fitnah karena adanya pencitraan ulang dari anggota kepolisian yang terlibat. Kemudian yang tak kalah penting adalah terkait istilah sadis yang diartikan kejam dan tidak mengenal belas kasihan, ini bisa dikaitkan dengan kekerasan yang mau tidak mau timbul dalam program jurnalistik Program Siaran

\footnotetext{
${ }^{15}$ Youtube, "Tim Tiger Dilempari Batu, Belasan Pelaku Tawuran Ngumpet di Rusun Warga", $<$ https://www.youtube.com/watch?v=FvryuchcSUI $>$, accessed on 7 May 2020.

${ }^{16}$ H. Wildan Suyuthi Mustofa, Kode Etik Hakim (Prenada Media).[112].

${ }^{17}$ Hamdan Daulay, 'Kode Etik Jurnalistik dan Kebebasan Pers di Indonesia ditinjau dari Perspektif Islam' (2008) 2 Jurnal Penelitian Agama.[306].

${ }^{18}$ Fitri Meliya Sari, 'Analisis Penerapan Kode Etik Jurnalistik pada Harian Serambi Indonesia.' (2014) 2 Interaksi: Jurnal Ilmu Komunikasi.[132].
} 
"86" ketika melakukan pengerebekan atau pengejeran. Berikutnya adalah cabul yang mungkin tidak secara eksplisit terlihat.

Pada Pasal 5 dinyatakan bahwa Wartawan Indonesia tidak menyebutkan dan menyiarkan identitas korban kejahatan susila dan tidak menyebutkan identitas anak yang menjadi pelaku kejahatan. Yang dimaksud Identitas adalah semua data dan informasi yang menyangkut diri seseorang yang memudahkan orang lain untuk melacak, sehingga dalam Program Siaran "86” Identitas para pelaku sudah seharusnya di buramkan karena apabila tidak diburuamkan ditakuktkan akan terjadi fitnah yang juga merupakan bagian dari kode etik jurnalistik, sehingga seseorang akan mengalami trial by the press padahal isi dari program ini merupakan proses sebelum pengadilan mengeluarkan keputusan sehingga belum tentu orang tersebut salah sesaui dengan apa yang ditayangkan pada Program Siaran "86”. Apalagi kaitannya dengan anak yang masih memiliki masa depan yang panjang.

Yang tak kalah penting adalah pernyataan pada Pasal 8 yaitu Wartawan Indonesia tidak menulis atau menyiarkan berita berdasarkan prasangka atau diskriminasi terhadap seseorang atas dasar perbedaan suku, ras, warna kulit, agama, jenis kelamin, dan bahasa serta tidak merendahkan martabat orang lemah, miskin, sakit, cacat jiwa atau cacat jasmani. Prasangka adalah anggapan yang kurang baik mengenai sesuatu sebelum mengetahui secara jelas. Berdasarkan penafsiran tersebut maka penayangan Program Siaran "86" terkait apa yang terjadi sebelum pengadilan mengeluarkan keputusan dapat dikatakan sebagai prasangka karena sesungguhnya belum dibuktikan di depan pengadilan apa kesalahan dari pelaku. Penilaian akhir atas pelanggaran kode etik jurnalistik dilakukan Dewan Pers. Sanksi atas pelanggaran kode etik jurnalistik dilakukan oleh organisasi wartawan dan atau perusahaan pers.

\section{Pertanggungjawaban bagi media televisi yang menyiarkan Program Siaran "86"}

Subjek hukum dalam pertanggungjawab pidana adalah setiap orang yang melakukan pidana. Pertanggungjawaban pidana diterapkan terhadap setiap orang 
yang melakukan perbuatan pidana, tidak terkeculai terhadap pers. ${ }^{19}$ Program Siaran “ 86 ” merupakan produk jurnalistik yang dikeluarkan oleh media televisi. Media televisi merupakan bagian dari media elektronik yang berada di bawah naugan Perusahaan Pers. Maka dari itu setiap media televisi yang melakukan pelanggaran sudah seharuasnya dimintai pertanggungjawaban.

\section{Pertanggungjawaban media televisi menurut KUHP}

Pertanggungjawaban tidak hanya dilihat dari perbuatannya saja, melainkan dilihat juga dari unsur kesalahannya. Asas ini lah yang dianut oleh KUHP. Dalam KUHP Indonesia hingga saat ini masih menganut bahwa suatu delik hanya dilakukan oleh manusia. ${ }^{20}$ Pers melibatkan banyak pihak yang mengingat kegiatan pers tidak dapat dilakukan oleh satu orang. Pers bersifat organisasi, dimana terdapat beberapa orang yang terlibat dalam pengolahan dan pembentukan suatu materi siaran.Banyaknya pihak yang terlibat dalam perbuatan pidana diatur dengan istilah deelneming (pernyetaan), yaitu perbuatan pidana yang dilakukan secara bersama. Untuk menentukan hukuman masing-masing orang tersebut, harus dilihat terlebih dahulu bagaimana dan sejauhmana keterlibatan mereka dalam tindakan tersebut.

Ketentuan penyertaan yang dibentuk dan dimuat dalam KUHP tujuannya adalah agar dapat dipertanggungjawabkan dan dipidananya semua orang yang terlibat dan mempunyai andil dalam tindakan tersebut baik secara fisik (obyektif) maupun psikhis (subyektif). ${ }^{21}$

Masalah deelneming diatur dalam Pasal 55 dan Pasal 56 KUHP. Pasal 55 mengenai golongan yang disebut dengan mededader (disebut para peserta, atau para pembuat) dan pasal 56 mengenai medeplichtige (pembuat pembantu).Dari uraian Pasal 55 KUHP, dapat diketahui bahwa ada empat golongan pelaku tindak

\footnotetext{
${ }^{19}$ Reka Bagus Wicaksono, Trial by The Press yang Mengakibatkan Pencemaran Nama Baik (2012) Program Doktoral Universitas Airlangga.[48].

${ }^{20}$ Intan Meyliawati Suyono Putri, Pornografi dalam Lembaga Penyiaran Televisi (2010) Program Sarjana Universitas Airlangga.[65].

${ }^{21}$ Adami Chazawi, Pelajaran Hukum Pidana (Percobaan dan Penyertaan) (Raja Grafindo Persada 2002).[71].
} 
pidana, baik pelaku kejahatan maupun pelanggaran, yaitu:

1. Pleger (orang yang melakukan);

2. Doen Plegen (orang yang menyuruh melakukan);

3. Medepleger (orang yang turut melakukan);

4. Uitlokker (orang yang membujuk melakukan).

Semua golongan yang disebut Pasal 55 KUHP tergolong kepada pelaku tindak pidana, sehingga hukuman buat mereka juga disamakan.

Dari uraian Pasal 56 KUHP, dapat diketahui bahwa ada dua golongan pembantu yaitu:

1. Pembatuan pada saat kejahatan dilakukan.

2. Pembantuan sebelum kejahatan dilakukan, yang dilakukan dengan cara memberi kesempatan, sarana atau keterangan. ${ }^{22}$

Dari penjelasan diatas dapat diketahui bahwa terdapat hubungan antara setiap pelaku sesuai tanggung jawabnya masing-masing dalam pengerjaan isi materi siaran. Lebih lanjut pengertian dari penyertaan dan siapa pihak yang termasuk dalam golongan penyertaan dalam kaitannya dengan Program Siaran "86” dalam Lembaga penyiaran televisi adalah sebagai berikut.

1. Pimpinan Stasiun Televisi

Pemimpin stasiun televisi adalah penanggung jawab dalam stasiun televisi. Tugasnya adalah memberikan arahan kepada semua produser acara yang akan dimuat pada stasiun televisi. Apabila dalam sebuah program acara stasiun televisi dipertanggungjawabkan secara pidana, dilihat dari apakah pemimpin stasiun televisi tersebut mengetahui atau tidak tentang isi materi program acara televisi tersebut.23 Apabila pemimpin stasiun televisi ikut dalam pembuatan kegiatan acara, seperti pembuatan isi materi bersama tim produksinya maka pemimpin stasiun televisi bisa disebut turut serta (medepleger).

2. Produser

Produser adalah pemimpin perencanaan dalam tim produksi. Produser menyiapkan topik siaran, menyiapkan sumber data, anggaran siaran dan durasi

\footnotetext{
${ }^{22}$ Reka Bagus Wicaksono, Op.Cit.[52].

${ }^{23}$ ibid. [58].
} 
penyiaran. ${ }^{24}$ Produser bertanggung jawab terhadap isi, pesan, dan informasi dalam program jurnalistikyang akan disiarkan kepada masyarakat. Berdasarkan Pasal 55 KUHP produser dikualifikasi sebagai pleger atau pelaku karena tanggungjawab yang dibawanya.

\section{Pengarah Acara (Program Director)}

Pengarah acara adalah pelaksana ide dari produser menjadi karya audio visual. Pengarah acara bertugas mengatur siaran. ${ }^{25}$ Apabila dalam siaran program jurnalistik terjadi delik pers, maka pengarah acara adalah salah satu yang bertanggung jawab. Berdasarkan Pasal 55 KUHP pengarah acara dikualifikasi sebagai medepleger atau turut serta.

\section{Tim Produksi}

Tim Produksi adalah yang bertanggung jawab terhadap pengoprasian alatalat teknik dalam siaran (kameraman, editor, dll). ${ }^{26}$ Apabila dalam program jurnalistikterjadi delik pers, tim produksi adalah salah satu yang bertanggung jawab. Berdasarkan Pasal 56 KUHP tim produksi dikualifikasi sebagai medeplichtige atau pembantu.

\section{Narasumber}

Terhadap narasumber program jurnalistik apabila didalam memberikan keterangan dalam Program Siaran "86" menimbulkan muatan delik pers, maka berdasarkan Pasal 55 KUHP narasumber termasuk orang yang melakukan (pleger).

\section{Pertanggungjawaban Media Televisi menurut Undang Undang Pers}

Pertanggungjawaban dalam bidang hukum pers meliputi arah dualisme pertanggung jawaban (dual responsibility), yaitu sisi pertanggung jawaban pers dan pertanggungjawaban pidana terhadap pers. ${ }^{27}$ Kemudian pertanggungjawaban pers setelah berlakunya Undang-Undang Nomor 40 Tahun 1999 tentang pers

\footnotetext{
${ }^{24}$ ibid.

${ }^{25}$ ibid. [59].

${ }^{26}$ ibid.

${ }^{27}$ ibid. [61].
} 
yang menerapkan sistem pertanggungjawaban pidana yang disebut vicarious liability atau pertanggungjawaban pengganti. Vicarious Liability memiliki makna pertanggungjawaban pengganti atau pertanggungjawaban menurut seseorang atas peruatan salah yang dilakukan oleh orang lain. Secara eksplisit diatur dalam penjelasan Pasal 12 dan Pasal 18 ayat (2). Pasal 12 yang menyatakan Perusahaan pers wajib mengumumkan nama, alamat, dan penanggung jawab secara terbuka melalui media yang bersangkutan; khusus untuk penerbitan pers ditambah nama dan alamat percetakan. Berdasarkan penjelasan Pasal 12 UU Pers, menyatakan yang dimaksud penanggung jawab adalah penanggung jawab perusahaan pers yang meliputi bidang usaha dan bidang redaksi, sepanjang menyangkut pertanggung jawaban pidana menganut ketentuan perundang-undangan yang berlaku. Makna yang berlaku tersebut dimaksudkan sebagai "individual responsibility" yang menyangkut actual and factual wrongdoer (pelaku utama). ${ }^{28}$ Sedangkan Pasal 18 ayat (2) menyatakan Perusahaan pers yang melanggar ketentuan Pasal 5 ayat (1) dan ayat (2), serta Pasal 13 dipidana, dengan pidana denda paling banyak Rp 500.000.000,00 (lima ratus juta rupiah). Kemudian berdasarkan penjelasan Pasal 18 ayat (2) Undang-Undang Nomor 40 Tahun 1999 tentang Pers, menyatakan dalam hal pelanggaran pidana yang dilakukan oleh perusahaan pers, maka perusahaan tersebut diwakili oleh penanggungjawab sebagaimana dimaksud dalam Pasal 12. Selain itu dari pasal 18 ayat (2) dimungkinkan ada pertanggung jawaban pers secara korporasi, yaitu apabila pers tidak menghormati normanorma agama dan rasa kesusilaan masyarakat serta asas praduga tidak bersalah, dan juga tidak melayani hak jawab, dapat dikenakan ketentuan pidana denda. Dari sini dapat diambil kesimpulan bahwa meskipun produser yang bertindak secara langsung dalam muatan isi siaran perusahaan pers harus menaggung akibatnnya, sehingga korporasi yang diakui sebagai subjek hukum adalah pihak yang harus bertanggungjawab.

${ }^{28}$ ibid. [27-28]. 


\section{Pertanggungjawaban Media Televisi menurut Undang Undang Penyiaran}

Bentuk dari media televisi adalah korporasi hal ini ditegaskan dalam pasal 14 ayat (1) UU Penyiaran yang menyatakan bahwa bentuk dari Lembaga penyiaran adalah badan hukum. Dengan demikian maka media televisi adalah suatu korporasi. Dalam UU Penyiaran sendiri deikenal bentuk sanksi administratif dan ketentuan pidana. Sanksi administratif ini diatur lebih lanjut dalam ketentuan yang dibuat oleh KPI bersama pemerintah. Sedangkan, Ketentuan pidana terhadap penyiaran diatur dalam pasal 57, pasal 58 dan pasal 59 UU Penyiaran. Berdasarkan Pasal 57 huruf d, mengatur sanksi pidana terhadap pelanggaran Pasal 36 ayat (5) yang dilakukan oleh Program Siaran “86” terkaitlarangan isi siaran dalam huruf a, isi siaran dilarang bersifat fitnah, menghasut, menyesatkan dan/atau bohong. Hal ini dapat diartikan bahwa apabila terjadi pelanggaran, yaitu terhadap isi siaran, salah satunya melalui siaran televisi, terdapat fitnah yang kemudian mencemarkan nama baik, seseorang yang bertanggung jawab dalam lembaga penyiaran tersebut (media televisi) dapat dijatuhi pidana. ${ }^{29}$ Pidana tersebut dapat berupa pidana penjara selama 5 tahun dan atau/ denda paling banyak Rp. 10.000.000.000,00 (sepuluh miliar rupiah). Dalam hal pertanggung jawaban pidananya, Lembaga penyiaaran dalam UU Penyiaran telah mengatur secara tersendiri dalam pasal 54 yang menyatakan Pimpinan badan hukum lembaga penyiaran bertanggung jawab secara umum atas penyelenggaraan penyiaran dan wajib menunjuk penanggung jawab atas tiap-tiap program yang dilaksanakan. Oleh karena itu, produser siaran yang bisa dikenai pidana penjara apabila terdapat pelanggaran isi siaran dalam suatu program acara. ${ }^{30}$ Namun program acara Program Siaran " 86 ” ditemukan tidak menayangkan penanggungjawab dalam materi siarannya, baik dalam pembuka, isi, maupun penutup acara. Sehingga, media telvisi selaku korporasilah yang harus bertanggungjawab atas pelanggaran terhadap pasal 36 ayat (5).

\footnotetext{
${ }^{29}$ Reka Bagus Wicaksono, Op.Cit.[64].

${ }^{30}$ ibid.
} 


\section{Pertanggungjawaban media televisi menurut kode etik.}

Untuk menjamin kemerdekaan pers dan memenuhi hak publik untuk memperoleh informasi yang benar, wartawan Indonesia memerlukan landasan moral dan etika profesi sebagai pedoman operasional dalam menjafa kepercayaan publik dan menegakkan integritas sera profesionalisme. Atas dasar itu wartawan Indonesia mentaati kode etik jurnalistik yang dietapkan oleh dewan pers. Dalam Kode Etik tersebut dinyatakan Penilaian akhir atas pelanggaran kode etik jurnalistik dilakukan Dewan Pers. Sanksi atas pelanggaran kode etik jurnalistik dilakukan oleh organisasi wartawan dan atau perusahaan pers. Sehingga meskipun perusahaan pers yang harus menanggung tanggungjawab apabila terjadi konflik dalam isi materi siaran, produser selaku pemimpin perencanaan dalam tim produksi tidak dengan mudahnya lepas tangan dari pertanggungjawaban. Produser harus bertanggungjawab seara internal kepada perusahaan pers (media televisi) yang bersangkutan. Bentuk pertanggung-jawabannya dapat berupa sanksi administratif seperti surat peringatan, pemindahan tugas atau diberhentikan tanggung jawab kebijakan yang telah disepakati dalam perusahaan pers tersebut. Sanksi tersebut sudah termasuk dalam code of enterprise.

KPI tidak memiliki wewenang untuk mencabut izin penyiaran. ${ }^{31}$ Terkait pihak yang akan dimintai pertanggung jawaban berdasarkan ketentuan ini disebut dengan jelas dalam pasal 76 yang menyatakan apabila terjadi pelanggaran maka yang bertanggungjawab adalah lembaga penyiaran yang menyiarkan program yang mengandung pelanggaran tersebut. Sehingga dapat dilihat bahwa meskipun Dewan Pers memiliki mekanisme dalam penyelesaian pelanggaran Kode Etik, KPI yang juga lembaga independen juga memiliki mekanisme terkait hal tersebut. Namun meskipun demikian, dapat dilihat bahwa kedua lembaga ini bekerja sama agar dapat menyelesaikan pelanggaran Kode Etik yang dilakukan oleh media televisi tersebut.

\footnotetext{
${ }^{31}$ Ranni Juwita, Peran Komisi Penyiaran Indonesia (KPI) Dalam Mengawasi Tayangan Sinetron Tukang Bubur Naik Haji Di Rcti (2015) Program Sarjana UIN Syarif Hidayatullah Jakarta.[5].
} 


\section{Kesimpulan}

Terdapat pelanggaran isi materi siaran yang diatur dalam UU Penyiaran pasal 36 ayat (5) selain itu isi materi siaran juga melanggar pasal 4 Kode Etik Jurnalistik yang menyatakan Wartawan Indonesia tidak membuat berita bohong, fitnah, sadis, dan cabul patut menjadi perhatian, sehingga lembaga penyiaran yang diposisikan sebagai wartawan menurut etik nya juga harus menghormati keberadaan asas praduga tak bersalah. Pelanggaran ini terjadi pada beberapa episode Program Siaran 86. KPI sebagai lembaga yang berwenang mengeluarkan surat peringatan No.554/K/KPI/31.2/10/2018 bagi Program Siaran "86” karena pelanggarannya pada episode yang dinilai berpotensi melanggar Pasal 15 Ayat (1) tentang kewajiban program siaran memperhatikan dan melindungi kepentingan anak.Pertanggungjawaban pidana bagi media televisi yang menayangkan Program Siaran " 86 ” berdasarkan UU Penyiaran sebagai lex specialiditanggung oleh produser sebagai penanggungjawab acara namun, karena pihak Program Siaran "86” tidak mencantumkan penaggungjawab acara maka berdasarkan pasal 54 media televisi dapat dimintai pertanggungjawaban. Sebagai pembanding apabila berdasarkan KUHP maka semua pihak dapat dimintai pertanggungjawaban menggunakan pasal 55 dan 56 sesuai dengan perannya,berdasarkan UU Pers maka media televisi sebagai perusahaan pers yang dapat dimintai pertanggungjawaban, dan berdasarkan kode etik maka pihak yang terlibat secara langsung akan dimintai pertanggungjawaban dengan melakukan hak jawab dan hak koreksi apabila melihat pedoman perilaku penyiaran maka yang bertanggungjawab adalah lembaga penyiraran.

\section{Daftar Bacaan}

\section{Buku}

Onong Uchyana Effendi, Ilmu Komunikasi (Teori dan Praktek) (Remaja Rasdakarya 2002).

Hermin Indah Wahyuni, Kebijakan Media Baru Di Indonesia (Harapan Dinamika Dan Capaian Kebijakan Media Baru Di Indonesia) (Ugm Press 2018).

H. Wildan Suyuthi Mustofa, Kode Etik Hakim (Prenada Media). 
Adami Chazawi, Pelajaran Hukum Pidana (Percobaan dan Penyertaan) (Raja Grafindo Persada Jakarta 2002).

\section{Jurnal}

Hanugrah Titi Habsari, 'Implikasi Hukum Asas Praduga Bersalah yang Digunakan Wartawan dalam Pemberitaan Perkara Pidana' (2017) 2 Arena Hukum.

Soediro, 'Perbandingan Sistem Peradilan Pidana Amerika Serikat dengan Peradilan Pidana di Indonesia' (2019) Kosmik Hukum.

Pretty BellaWajong, 'Perlindungan Hukumbagi Wartawandalam Melaksankan Tugas dan Fungsi Terkait dengan Kebebasan Pers Menurut Undang-Undang Nomor 40 Tahun 1999.' (2018) 2 Lex Et Societatis.

Sukardi, W. A., 'Menghindari Tuduhan Pelanggaran Asas Praduga Tidak Bersalah' (2010) 2 Jurnal Dewan Pers.

Risa Badril Moenir, 'Kecenderungan Pelanggaran Pedoman Perilaku Penyiaran dan Standar Program Siaran (Studi Analisis Pada Kasus Pelanggaran Pedoman Perilaku Penyiaran dan Standar Program Siaran Media Televisi yang Dimuat di Website kpi.go.id)' 1 Jurnal Ilmu Komunikasi Flow.

Hamdan Daulay, 'Kode Etik Jurnalistik dan Kebebasan Pers di Indonesia Ditinjau dari Perspektif Islam' (2008) 2 Jurnal Penelitian Agama.

Fitri Meliya Sari, 'Analisis Penerapan Kode Etik Jurnalistik pada Harian Serambi Indonesia.' (2014) 2 Interaksi: Jurnal Ilmu Komunikasi.

\section{Skripsi}

Amanda Paramitha, Karya Film Dokumenter mengenai Kehidupan Seorang Anak Perantau dari Kabupaten Alor, Nusa Tenggara Timur di Pesantren At-Tamim Kabupaten Bandung (Program Sarjana Universitas Pasudan 2017).

Intan Meyliawati Suyono Putri, Pornografi dalam Lembaga Penyiaran Televisi (Program Sarjana Universitas Airlangga 2010).

Ranni Juwita, Peran Komisi Penyiaran Indonesia (KPI) Dalam Mengawasi Tayangan Sinetron Tukang Bubur Naik Haji Di Rcti (Program Sarjana UIN Syarif Hidayatullah Jakarta 2015).

\section{Tesis}

Muhammad Imam Baihaqi, Konstruksi Realitas Sosial Citra Polisi Pada Reality 
Show Net Program Siaran "86" Di Net. TV (Program Master UIN Syarif Hidayatulah Jakarta 2016).

\section{Disertasi}

Reka Bagus Wicaksono, Trial by The Press yang Mengakibatkan Pencemaran Nama Baik (Program Doktoral Universitas Airlangga 2012).

\section{Laman}

'Mengenal Konvenan Internasional Hak Sipil dan Politik', <https://icjr.or.id/ mengenal-kovenan-internasional-hak-sipil-dan-politik/>, accessed on 28 May 2020.

Nevrina Hastuti, 'Eksistensi Sistem Juri dalam Sistem Peradialan Pidana di Amerika Serikat', <https://jabar.kemenkumham.go.id/berita-kanwil/berita-utama/ eksistensi-sistem-juri-dalam-sistem-peradilan-pidana-amerika-serikat>, accessed on 10 May 2020.

Adv, "86 Program TV Baru yang Mengungkap Realita Kehidupan Polisi", $<$ https:// hot.detik.com/advertorial-news-block/d-2655975/ '86'-program-tv-baruyang-mengungkap-realita-kehidupan-polisi>, accessed on 15 May 2020.

Youtube, "Tim Tiger Dilempari Batu, Belasan Pelaku Tawuran Ngumpet di Rusun Warga", <https://www.youtube.com/watch?v=FvryuchcSUI $>$, accessed on 7 May 2020. 